\title{
Можливості застосування електрозварювання живих тканин для герметизації дефектів паренхіми при хірургічному лікуванні хворих на туберкульоз легень
}

Іващенко В.Є., Калабуха І.А., Хмель О.В., Брянський М.В.

ДУ «Національний інститут фтизіатрії і пульмонології ім. Ф.Г. Яновського НАМН України», м. Київ, Україна

Обґрунтування. При оперативних втручаннях на легенях, уражених туберкульозом, на різних етапах виникає необхідність герметизації дефектів паренхіми, що з'явилися під час роз'єднання зрощених запальним процесом листків плеври, розділення часток легені та, власне, резекції ураженої ділянки легені. Серед наявних методів герметизації з 2010 р. у нашому відділенні віддається перевага техніці біологічного зварювання живих тканин.

Мета. Оцінити ефективність і переваги біологічного зварювання живих тканин для герметизації дефектів паренхіми під час операцій у хворих на туберкульоз легень.

Матеріали та методи. Було проаналізовано результати лікування 234 хворих на туберкульоз легень. У 122 паці$\epsilon$ нтів для герметизації дефектів, у тому числі механічного шва паренхіми, було застосовано зварювальний комплекс EK 300 M1. Групу порівняння становили 112 пацієнтів, яким герметизацію відновлювали за допомогою ручного вузлового шва. Критеріями порівняння були: частота інтраопераційних або післяопераційних ускладнень, тривалість післяопераційного лікування, частота рецидивів захворювання, легенево-плевральних ускладнень, середня тривалість післяопераційного лікування. Дослідження виконувалося коштом держбюджету.

Результати та їх обговорення. Ми порівняли результати оперативного лікування хворих на туберкульоз легень із герметизацією дефектів паренхіми традиційним способом (прошивання вузловими швами) та методом зварювання живих тканин. Інтраопераційних або післяопераційних ускладнень у основній групі не було, тривалість післяопераційного лікування становила 15,7+3,2 доби. Протягом 1 року після операції рецидивів захворювання не спостерігалося. У групі порівняння легенево-плевральні ускладнення спостерігалися в 10 випадках (8,9+1,8 \%), що спонукало до виконання додаткових хірургічних маніпуляцій і додаткової медикаментозної терапії та стало причиною подовження післяопераційного лікування: від 24 до 117 діб (в 1 випадку), середня тривалість 32,3+6,9 доби.

Отже, порівняно з традиційним, представлений спосіб має такі переваги: не виконується додаткових аеростатичних і гемостатичних швів; зберігається міцність шва; не порушуються еластичні властивості тканини в зоні шва; запобігаються післяопераційні ускладнення; зменшується потреба в хірургічних маніпуляціях у післяопераційному періоді; утворення шва минає без стадії продуктивного запалення; скорочується термін післяопераційного перебування в стаціонарі на 9,6+1,7 дня.

Висновки. Застосування техніки біологічного зварювання живих тканин позбавляє багатьох недоліків, які пов'язані з прошиванням паренхіми вручну, запобігає ускладненням і підвищує загальну ефективність лікування хворих на туберкульоз легень. 